\title{
TRAINING OF MAKING MEGONO ROLLS MOTHER'S PKK KRAPYAK DISTRICT, NORTH PEKALONGAN TO PRESERVE TRADITIONAL FOOD SPECIALLY PEKALONGAN
}

\author{
Raden Nana Kusdiana, Trias Septyoari Putranto, Sarim \\ Bina Nusantara University, Indonesia \\ rkusdiana@binus.edu
}

\begin{abstract}
In general, the view of a housewife about entrepreneurial activities is one of the activities that can be done to increase family income and fill spare time. This entrepreneurial activity needs training and assistance. This was done because of lack of knowledge and benefits that can be received by these mothers. Megono Rolls can be an alternative business activity that can be carried out by these mothers in order to preserve the traditional food typical of Pekalongan. The focus of this research is the process of empowering women through training and assistance in making a good Megono Rolls, so that PKK women can have activities that produce and help the economy in the area. Data collection techniques used in this study were observation, interviews and documentation. The data obtained were analyzed using data analysis techniques. The results of the study stated that the process of empowering PKK mothers through the skills training in making Megono Rolls by prescribing and teaching the manufacture of Megono Rolls correctly and hygiene and training on the use of appropriate materials and tools until the manufacturing process will produce good products. So that the results of this Megonon Rolls will become better known and even re-popular as a traditional Pekalongan food.
\end{abstract}

\section{Keywords: Training, Megono, Traditional Food, Typical Pekalongan}

\section{INTRODUCTION}

Food or culinary is an identity or reflects the culture of a nation. Indonesia is famous for a variety of traditional foods that are popular with not only Indonesian tourists but also foreign tourists. Each region throughout the archipelago has a special food. Pekalongan City has the potential of very attractive tourist attractions to visit, both cultural and natural attractions that are no less competitive in terms of quality with other regions. Examples of cultural attractions in the form of batik handicrafts and performing arts and no less interesting are local foods that are potential to be marketed to tourists both local, domestic and foreign. One alternative form of tourism development in Pekalongan City is culinary products. Culinary tourism will offer a gastronomic experience of local food that has a distinctive taste. Processed ingredients, food appearance, and interesting tastes according to tourist tastes also become an advantage of local cuisine, so that these types of local cuisine are generally acceptable to tourists.

The potential of this local cuisine can be a way or answer to start or open a tourism development effort in Pekalongan City through the development and marketing of culinary tourism products in Pekalongan City. Furthermore, a culinary tourism product development model must be made appropriate and adapted to the potential and strength of Pekalongan City. Some local dishes that have been quite famous so far, namely Nasi Megono, Tauto, Garang Asam, Pindang tetel, Kluban, Kripik Tahu. Some examples of local cuisine above from observation so far have become a kind of icon in the Pekalongan area, many tourists are interested in tasting the local cuisine and even they are interested in consuming it again on their next arrival. Processed ingredients, the appearance of dishes, and interesting tastes according to tourists' tastes also become an advantage of local cuisine, so that these types of local cuisine are generally acceptable to tourists. The potential of this local cuisine can be a way or answer to start or open a tourism development effort in Pekalongan City through the development and marketing of culinary tourism products in Pekalongan City. Furthermore, a culinary tourism product development model must be made appropriate and in accordance with the potential and strength of the City of Pekalongan.

Restaurants and businesses in the field of food, especially as a regional specialty are very important aspects in the development of the tourism industry. Various types of restaurants and businesses in the field of food were developed, as well as various menus, both types of food and drinks served with a variety of innovative creations. Local food and outdoor food are served in various restaurants to meet the needs of every tourist for food and drinks. 


\section{FOOD GASTRONOMY}

Gastronomy or catering is the art or science of good food (good eating). Gastronomy as everything related to the enjoyment of eating and drinking. The term gastronomy first appeared in the title of a poem in France in 1801 (Berchoux, 1804 in Scarpato, 2002) relating to the enjoyment of enjoying food and drinks. Gastronomy was also introduced by Jean Anthelme and Brillat Savarin (1994) in his book entitled La Physiologe du Gout (the physiology of taste), which states that gastronomy is a pleasure in eating good quality food and a reflection of the process of consumption and food processing. Furthermore Ardika (2011) added that gastronomy also includes detailed knowledge of national food and drinks from various major countries throughout the world. The role of gastronomy is as a basis for understanding how food and drink are used in certain situations. Gastronomic theory is used to analyze the problems in this study, specifically to examine the types of traditional foods that can be developed as a culinary tourism attraction in Pekalongan, including the uniqueness in terms of processing and serving these foods. In addition, this theory is also used to see a variety of traditional drinks (including the manufacturing process) that can be a culinary tourism attraction.

Due to the many points of view given by scientists related to the understanding of the science of gastronomy as mentioned above. This study draws on the understanding presented by Ketaren (2016) which informs and describes gastronomic science according to the topic of the discussion. Ketaren (2016, pp. 9-10) said that there were 5 (five) aspects that distinguished discussions related to the science of gastronomy, namely:

1. Practical Gastronomy

Practical activities to change raw food ingredients to be served consisting of activities of application, preparation, production, and food service activities

2. Theory of Gastronomy (Theory of Gastronomy)

Theoretical discussions that describe food processes, systems and recipes, often produce academic papers or reviews.

3. Technical Gastronomy (Technical Gastronomy)

Activities carried out by one or more culinary experts, food technology experts, consultants, professional practitioners and entrepreneurs in relation to providing systematic assessment, evaluation and cooking skills.

4. Molecular Gastronomy (Molecular Gastronomy)

Discusses the physics-chemical transformation process rather than food processing sourced from raw materials used during the cooking process and the method of presentation.

5. Food Gastronomy

Discussion of the food menu from several perspectives such as history, socio-culture, geographical value, and cooking methods.

In this case, the article would like to look the Megono menu from the food gastronomy point of view. Food gastronomic is used to achieve the objectives of a research, especially to study and review the Megono menu towards historical, socio-cultural within the Pekalongan city, its geographic value and cooking method such as the use of basic materials and the making of the menu, including its uniqueness in terms of processing and presentation of the food. In addition, this theory approach is also used to see the process rather than making the menu under study to be able to make it a potential culinary attraction. Food gastronomy theory is looking from actor's point of view who support practical gastronomy by studying the Megono historical value, processes, systems of recipes that are implemented into academic or scientific writing. In order to do so, the review will go towards the menu document and formulate various kinds of procedures that must be done to maximize learning and efficiency of food processing and improve the success in processing the food dish.

\section{RESEARCH METHOD}

With a limited number of research conducted on the food tourism, particularly towards gastronomy. Whilst, Atkins and Wallace uses qualitative methodological terms of "people-focused"- instead of "objective" study that represent quantitative methodological terms. A qualitative research method that pressed an insight into individuals' perceptions regarding several issues of concern is suitable for this article to be conducted especially in the subject concerning about tourism. Bryman argued that qualitative research strategy is broadly constructionist, inductivist, and interpretivist by nature. Therefore, the qualitative research method to review Megono menu as traditional menu development would inform this research method. The workshop of megono rolls to several stakeholders surrounded area of Krapyak district, North Pekalongan of Pekalongan city were established. Regardless the demographic concern, knowledge, understanding, and perceptions about menu items understand Megono as a traditional food in Pekalongan where product innovations are carried out on this megono through training with families of mothers in the Krapyak area. Finally, the results produce the conclusion and critical discussion on Megono rolls as the Pekalongan's traditional menu development. 


\section{FOOD GASTRONOMY OF MEGONO}

Megono rice as one of the culinary specialties of Pekalongan City shows the historical roots in a typical comestible in Indonesia. If studied, almost all typical foods in Indonesia have very strong historical roots. Usually, things that have a strong history like this are very interesting for foreign tourists. In addition to foreign tourists, this kind of thing is also quite interesting to be studied by native Indonesians. Because from this we can also learn the culture of our ancestors which is very diverse and very thick with philosophical values in it. Actually this megono rice was originally a offering that is very thick with Hinduism. It is only natural, because before Islam came to Java, the average Javanese population embraced Hinduism. So at that time, this megono rice was still in the form of an offering given to commemorate a certain day which was sacred in Hinduism. In addition, offerings are also given with the aim of asking for blessings from the goddess of rice, or better known as Dewi Sri.

The history of this megono rice actually begins with the culture of the Yogyakarta Palace precisely at the time of the Ancient Mataram Kingdom. Customs at that time still often held offerings for the ceremonial roast. Bekakak offerings are generally divided into three groups. 2 groups for two prisons which are put together with the bride and groom. While one offering is placed in a jodhang as a complement to the ceremony. That is actually the beginning of the megono with a form that is still in the form of rice cone, the edges are given with warehouses or ointments lizard or gori (nagka that is still young). The typical method of the Pekalongan community at that time was to store or shredded ointment or gori (young jackfruit) which was cut into small pieces and then added with spices in the form of grated coconut and spices that were either steamed or steamed first.

In the pantura area, including Pekalongan, once such offerings were used when there was an alms ritual for Dewi Sri the rice ruler. The aim is so that the harvest is abundant and also prosperous. So at that time generally megono cone was used for offerings given to Dewi Sri. It was only after the entry of Islam megono experience changes. Because generally this megono is used as a treat during tahlil and tahmid events in mosques. This megono rice is no longer used as offerings, but is generally distributed for food together. Uniquely, the megono rice is no longer made for cone at religious events, but has become part of the food industry in the city of Pekalongan.

\section{Name of the menu Megono Rolls Ingredients Skin Dough \\ - $\quad$ Chicken Egg 1 piece \\ - $\quad 150 \mathrm{ml}$ coconut milk \\ - $\quad$ Flour 50 grams \\ - $\quad$ Salt to taste \\ - $\quad$ Right amount of oil \\ How to make:}

1. Skin: mix well with flour, salt, coconut milk and eggs.

2. Make a thin pancake on a small flat pan / Teflon that is greased with a little oil. Set aside.

3. Contents: Megono Pekalongan

4. Take a piece of omelette. Give contents. Fold and roll.

5. Steam for 15 minutes over medium heat until cooked. Cool it down.

6. Fry in oil that has been heated over medium heat until golden brown.

\section{MEGONO PEKALONGAN}

- $\quad$ Young jackfruit (gori), chopped roughly 500 grams

- $\quad$ Half-old coconut, grated. 0.5 pes

- 6 shallots

- $\quad$ Garlic 3 cloves

- Coriander 1 teaspoon

- $\quad$ Candlenut 3 seeds

- $\quad$ Shrimp paste 1 teaspoon

- $\quad$ Kencur (Kaempferia galanga) 2 internodes

- $\quad$ Salt to taste

- $\quad$ Red chili, sliced 4 pcs

- Lemongrass leaves, 1 stem

- Kecombrang / honje flowers, roughly sliced, to taste

- $\quad$ Melinjo leaves, roughly sliced, to taste

- $\quad$ Salam leaves 2 pieces

- $\quad$ Galangal (Laos), 2 sections

- $\quad$ Kaffir lime leaves, take the leaf bone. 2 sheets

- Sugar to taste 
- Grinded shallot, garlic, coriander, candlenut, shrimp paste, kencur, salt and sugar.

- Arrange all the ingredients in a row from the bottom, chopped young jackfruit, grated coconut, herbs and other ingredients on it, steaming 30-45 minutes.

- Remove and mix all these ingredients, ready to serve.

\section{CONCLUSION}

From the standpoint of food cooking expertise, megono as a traditional menu from Pekalongan will be categorized as a complementary menu and have historical value, this can be raised and marketed by introducing innovations from the menu to the market. Introducing the public that megono which is a complementary food can be used as a snack. This innovation only adds parts of the skin that look like spring rolls and the contents of megono Pekalongan are added. So training must be carried out for the process of making the megono roll skin, while for the making of its contents the Pekalongan community is accustomed to cooking activities in their family environment. Thus making it easier for people to make innovations from authentic traditional products that are better and worth selling. With a need for further deconstruction of the ways each dimension of sustainability on a traditional menu megono rolls, - historical, socio-cultural, geographic value, and cooking method - independently enhances opportunity to bridge relations across certain diverse groups and foster an environment conducive to share. It also provides the critical thinking for megono rolls as the authentic traditional Pekalongan cuisine to re-introduce and have the opportunity to develop and convert into popular dishes. The food gastronomy examination on the megono rolls menu could provide a clear discussion and new thinking for the traditional menu to have development initiative. Opportunities to enhance sustainability through this menu megono rolls were further narrowed through socio-cultural and historically informed relations, where the continued importance of the menu ingredients, process and production are essentials aspects for preserving the value and uniqueness of the menu. Care needs to be upheld in regard to the extent to which enhancement of the traditional menu development through a specific 'community'. Food gastronomy point of discussion prove to be able to produce the framework thinking for megono rolls menu to get examination and evaluation in order to help to involve in both thinking of regional and local development in term of product preservation and sustainability of the menu.

\section{REFERENCES}

Adi, A. (2013). Analisis Strategi Pemasaran Makanan Tradisional (Studi Kasus Pada Home Industry Rengginang Halimatus Sa'diyah Kalibaru di Kabupaten Banyuwangi). Jember: Universitas Jember, Fakultas Ekonomi.

Angelina Rianti, Agnes E. Novenia, Alvin Christopher, Devi Lestari, Elfa K. Parassih, 2018, Ketupat as traditional food of Indonesian culture, Journal of Ethnic Foods Volume 5, Issue 1, March 2018, Pages 4-9

Anggreani, P. (2015). MENU POPULER HINDIA BELANDA (1901-1942): KAJIAN PENGARUH BUDAYA EROPA TERHADAP KULINER INDONESIA. Jurusan Sejarah Fakultas Ilmu Sosial Universitas Negeri Malang

Blankod, R. (2014). STUDI KOMPARATIF TRADISI KETUPAT (Suatu Penelitian Di Yosonegoro dan Atinggola). JURUSAN PENDIDIKAN SEJARAH, FAKULTAS ILMU SOSIAL UNIVERSITAS NEGERI GORONTALO

http://travel.kompas.com/read/2014/08/30/045100827/Ketua.BPPI.Pariwisata.Harus.Masuk.Sektor.Unggulan.

https://salasasite.wordpress.com/2016/02/02/ketupat/

Indar Widowati, Hartati, Zaenal Amirudin, 2018, KEMASAN MAKANAN KULINER TRADISIONAL "MEGONO" SEBAGAI UPAYA MEMPERPANJANG WAKTU SIMPAN DAN DAYA SAING PRODUK, Jurnal Litbang Kota Pekalongan Vol. 15 Tahun 2018

Jean Anthelme \& Brillat Savarin (1994). The Physiology of Taste: Or Transcendental Gastronomy

Harpa, W. (2011). Analisis Atribut Produk Pada Industri Dodol Kentang Karya Mandiri di Kecamatan Siulak Kabupaten Kerinci Provinsi Jambi. Padang: Fakultas Pertanian Universitas Andalas.

Kementrian Pariwisata \& Ekonomi Kreatif (2012). Rencana Pengembangan Kuliner Nasional 2015-2019

Ketaren, I. (2016). Gastronomi Upaboga Indonesia. Jakarta: Indonesian Gastronomy Association.

Koentjaraningrat. (1993). Metode Penelitian Masyarakat, Gramedia Pustaka Utama, Jakarta. 
Mantu, R. (2015). Resolusi Konflik Berbasis Budaya Lokal (Studi Tentang Tradisi Perayaan Hari Raya Ketupat Sebagai Upaya Membangun Hubungan Harmonis Muslim-Kristen di Kota Manado). Thesis UIN Yogyakarta

Moleong, Lexy J., (2007), Metodologi Penelitian Kualitatif, Bandung: Penerbit PT Remaja Rosdakarya.

Nyoman Adiputra (2015). KELAPA DALAM BUDAYA BALI SERTA UPAYA PELESTARIANNYA. Jurnal Bumi Lestari, Volume 15 No. 1, Pebruari 2015, hlm. 87 - 91

Podungge, S.R. (2015). PERSEPSI MASYARAKAT TENTANG TRADISI BA'DO KETUPAT (Studi Kasus di Desa Yesonegoro Kecamatan Limboto Barat Kabupaten Gorontalo). JURUSAN PENDIDIKAN SEJARAH, FAKULTAS ILMU SOSIAL UNIVERSITAS NEGERI GORONTALO

Rani Asmarani, 2018, TRANSLATING THE UNIQUE FOLKLORE OF GIANT LOPIS FEAST AND GIANT CONE MEGONO IN PEKALONGAN SYAWALAN TRADITIONS, Advances in Social Science, Education and Humanities Research (ASSEHR), volume 188 UNNES International Conference on English Language Teaching, Literature, and Translation (ELTLT 2018)

Saraswati, L.A. \& Wardhani, A.I. (2012). Perjalanan Multikultural dalam Sepiring Ketupat Cap Go Meh. Prosiding Seminar Internasional Multikultural \& Globalisasi

Simanjuntak, P., Fariadi, H., \& Yuli, R. (2014). Prospek Pengembangan Usaha Dodol Pepaya (Carica Papaya L.)Pada Home Industri "Dua Saudara" Desa Tebat Monok Kecamatan Kepahiang Kabupaten Kepahiang. AGRITEPA Vol.I, No.1.

Sugiyono. (2013). Metode Penelitian Pendidikan. Pendekatan Kuantitatif, Kualitatif, dan R\&D. Bandung: Alfabeta 